\title{
簡潔な経路情報を基にした移動ロボットの誘導法
}

\author{
西 川和 弘* 森 英 雄*
}

\section{Mobile Robot Navigation Using Brief Route Information}

\author{
Kazuhiro Nishikawa* and Hideo Mori*
}

\begin{abstract}
This paper proposes a navigation system for a mobile robot moving in an outdoor environment with brief route information. Our approach to visual navigation is based on the ability to find and track road boundaries in the environment. The brief route information for navigating the robot is represented with motion directions (e.g. right, left) at the intersections and metric distances between the intersections. The system consists mainly of two modules. One is to move along a road autonomously. The other is to monitor the robot actions and to navigate it so that the robot does not deviate from the route indicated by the route information. Generally speaking, it is difficult to navigate the robot in an outdoor environment since the ground is not flat and the images taken through the camera contain some noises. We have evaluated its navigational capability with experimentations in the real environment. As a result, it is confirmed that the system can robustly navigate the robot over a long path.
\end{abstract}

Key Words: Autonomous Mobile Robot, Visual Navigation, Route Information, Outdoor Environment

\section{1.はじめに}

移動ロボットを目的地まで誘導するには, 出発地点から目的 地に至る経路情報を何らかの方法で，ロボットに与えなければ ならない. 従来の研究として, 環境構造の幾何的な記述を地図と してロボットに与える方法 [1]〜 [3] や，環境内に点在するラン ドマークを記した地図によってロボットを誘導する方法 [4] [5] がある。これらの地図を利用した誘導法では，ロボットはセン サ情報と地図に記された部分的な環境の構造やランドマークを 比較することで, 地図上での自己位置を推定しながら移動する しかし，これらの定量的に記述された地図を利用する方法は， センサ情報に大きな誤差が含まれる場合，ロボットの位置決め が難しくなる．例えば, ロボットの運動を測定するために車軸 に取り付けられたエンコーダは, 車輪のスリップ等による誤差 を伴いやすい，また，超音波センサや視覚センサから得られる 距離情報は, 複雑な物体の形状や環境の変化に対して頑健では ない.さらに,これらの地図は環境の綿密な調査の基に作成さ れるため, 環境の変化に伴う地図の管理, 更新は容易ではない. その上, これらの問題点は, 屋外環境になるといっそう顕著に 現れる。

このような地図を利用するロボットは, 地図に記された環境 構造や, ランドマークを参照することで, 自らが移動可能な通

原稿受付 1993 年 12 月 1 日

*山梨大学工学部

* Faculty of Engineering, Yamanashi University
路に位置するかどうかを知る。一方人間は，地図を，自らが通 路上に位置しているかどうかを確かめるためには利用しない． これは，人間が道路や通路を認識し，それに沿って歩く能力を 有するからである。したがって，人間は道路地図や住宅地図を 利用しながら移動する場合にも，目的地に到達する間に現われ る部分的な環境構造（曲がり角等）やランドマークを確認する だけである．すなわち，人間は道路や通路を認識する能力を基 に環境内を移動し，地図を参照することで，たどるべき経路を 確認しながら目的地に到達する。

本稿で提案する移動ロボットのシステムは，この考えに基づ いて構築されている.システムは, 自律的に通路を発見し, 通 路に沿って移動する機能と，経路情報により指示された経路か ら逸脱しないようにロボットの行動を監視する機能から構成さ れる.このシステムは, 以下の特徴を持つ.

（1）システムに与える経路情報の作成が容易である.

（2）システムが通路を発見する機能を持つ.

（3）システムが屋外環境において頑健である.

ロボットが, 通路を発見, 追跡する機能を基に移動すること で, 移動経路は通路が分岐している地点（交差点）に関する記 述のみで簡潔に表現することができる。したがって，経路情報 の作成が容易である、ロボットによって観測される物体の位置 情報を定量的に厳密に記述する研究 [1]〜 [3] では，その環境モ デルの作成が容易にはできない。

道路追跡の研究 [6]〜 [8] は, 自動車の自動運転に関する分野 で数多く行われている.これらの研究との相違点は, ロボット 
が通路を発見する機能を持つことである. 道路追跡の研究では, 道路追跡を始める初期状態において, 道路はカメラの画像に投 影されるものとしているため, ロボットは道路を探し出す必要 がない、本研究では, ロボットが通路を発見する機能を持つこ とで，より自律的な移動を実現している.

システムは, 正確な環境モデルを基にした従来の方法では, ロボットを誘導することが難しい屋外環境において頑健である。 また, 人間の行動に基づいて選び出された経路情報の利用に関 する研究 $[10][11]$ があるが, 長距離の誘導においてどれほど有 効であるかは明らかにされていない. 本研究の新規性の一つは, 長距離の経路誘導を行える手法を提案し, 実環境における実験 により検証している点である.

本稿では, 上記した特徴を持つ視覚移動ロボットのシステム について述べ, 路面の凹凸や障害物等が存在するキャンパス内 通路での実験結果を示すことで, システムの有効性を明らかに する。

\section{2. 簡潔な経路情報を基にした誘導}

ロボットが通路に沿って移動するには, 最初にロボット周辺 の領域から通路を発見する必要がある。通常, 通路の両わき には他の領域との境界線が存在するので, ロボットは, この通 路の特徴を利用して通路を発見する。また, 通路に沿って移動 するには，ロボットの進行方向を通路と平行にする必要がある ため, 通路境界の方向を検出し, ロボットの進行方向を制御す る，指定された経路に沿って移動するには，経路上の交差点を 認識する必要がある，交差点の検出は，通路境界の端点におい て, 通路を発見する機能を利用して行う。このような方法で, ロボットは環境内を移動する

この方法を基にロボットを目的地まで誘導するには，たどる べき経路に沿って現れる各交差点に関する情報をロボットに与 える必要がある。経路情報は, 検出した交差点が指定された交 差点であるかを確認するための情報と，指定された交差点での 移動方向に関する情報を持つ、ロボットは, 前者の情報を用い て, 経路情報に記された交差点を逐次, 認識していくことで, 経路情報上の現在位置を推定する。また，ロボットは，後者の 情報を用いて, 指定された交差点で適切な通路を選択して, 目 的地まで到達する

\section{3. 経路情報の記述}

ロボットには, 目的地までの経路に沿って現れる交差点での 定性的な移動方向（十字路であれば, 左折, 直進, 右折）と, 各交差点間の距離を与える。このとき, 経路情報に記述する交 差点は，人間によって認識される交差点である。このため，口 ボットによって検出される交差点は, 人間が認識する交差点以 外の場所にも存在するかもしれないが, それらは無視されるこ とになる。

経路情報に記す交差点間の距離情報の解像度は，環境や口 ボットの運動能力に依存する。本研究の場合, 交差点を発見す るロボットにとって十分厳密で，ロボットに指令を与える人間 にとって，できるだけ扱いやすい距離の単位を決める必要があ る. 交差点間の距離情報は, 検出した交差点が指示された交差
点であるかを確認するために利用する。したがって，その距離 情報は，ロボットの走行する環境を考慮して，最低でも環境内 の隣り合った二つの交差点を区別できる, 距離の解像度を持つ 必要がある。例えば，その距離を $10[\mathrm{~m}]$ 単位で記述した場合、 目的の交差点の $10[\mathrm{~m}]$ 前後の範囲に他の交差点がなければ，ロ ボットは自律的に交差点を発見する能力を有するために，正し い交差点を発見することができる。我々は，キャンパス内で実 験を繰り返し，その妥当な距離の単位を決定した。その結果， ロボットへの距離情報は $1[\mathrm{~m}]$ 単位の指定で，その役割を確実 に果たすことが分かった。この值は, 経験的に割り出した值だ が，本研究が対象とするキャンパス内道路の交差点間距離の平 均值は $31[\mathrm{~m}]$, 最小值は $12[\mathrm{~m}]$ であることからも，十分に妥 当であることが裏付けられる．

例えば，経路情報として“50 [m] 進んだ先の交差点を左折し， 次に $35[\mathrm{~m}]$ 進んだ先の交差点を右折し,さらに $12[\mathrm{~m}]$ 進む” をロボットに教える場合, 以下に示すコマンドを経路情報とし てロボットに与える．

$$
\text { (forward, 50, left, 35, right, 12) }
$$

このような経路表現は, 人間が日常が用いる経路表現に近いも のと考えられ，ロボットに指令を与える人間にとって扱いやす い表現といえる。

\section{4. 移動ロボット}

実験に用いた移動ロボット晴信 4 号機（Fig.1 参照）につい て説明する。このロボットは, 従来の 4 号機 [12] を大幅に改良 し, 小型化と屋外環境における耐久性の向上をはかったロボッ トである. 車体は, 前輪が 2 輪独立駆動, 後輪がキャスター機構 からなる 3 輪構造で, 車体寸法は $105(\mathrm{~L}) \times 74(\mathrm{~W}) \times 107(\mathrm{H})[\mathrm{cm}]$ である，発電機を登載した台車を牽引することで，完全に自律 的なシステムとなる. 走行可能な時間は約 2 時間である.

外界センサとしては，ビデオカメラ (SONY Handy Cam V30 広角レンズ装着) と二つの反射型光電センサ（サンクス (株) PX1-DM3N）を装備している。ビデオカメラと光電セン サ 1 は, 水平方向に回転可能な回転台に取り付けられ, ロボッ

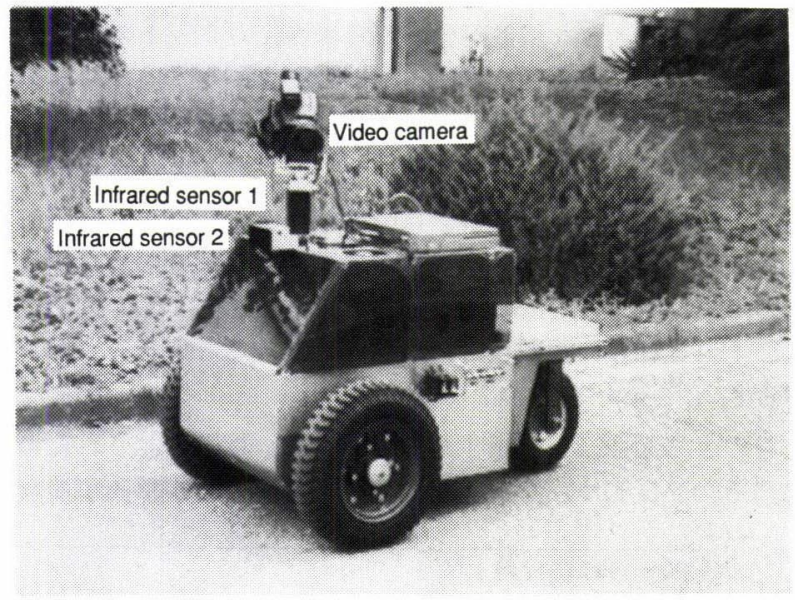

Fig. 1 Mobile robot HARUNOBU-4 
トの方向とは独立にセンサの方向を制御することができる．こ の回転台により, ビデオカメラと光電センサ 1 はロボットの周 囲半径 $5.5[\mathrm{~m}]$ と $2[\mathrm{~m}]$ の範囲をそれぞれ観測できる. 光電セ ンサ 2 は，ロボットに固定され，ロボットの前方約 $1.5[\mathrm{~m}]$ 以 内の障害物の有無を探知することができる.

内界センサとしては, 左右の駆動輪に取り付けられたエン コーダと, 光ジャイロ（日立電線(株) OFG-3）を装備しており, エンコーダは車輪一回転当たり 6 万パルスを発生する．車体は 指示された直線軌道に向かって，なめらかに移動する能力を持 つ [13].内界センサの情報収集と車体制御にはラップトップコ ンピュータ (CPU80286, $10[\mathrm{MHz}])$ ，その他の処理には VME コンピュータ（CPU68030, 25[MHz]）を使用する。この二つ のコンピュータはシリアルポート（RS-232C）を介して通信を 行う.

\section{5. システム構成}

システム構成を Fig. 2 に示す. システムは, 指示された経 路から逸脱しないようにロボットの行動を監視する機能と，口 ボットを自律的に通路に沿って移動させる機能から成る.ロボッ トの運動を監視する機能は, Global Route Manager (GRM) と Local Route Manager (LRM) の二つのサブシステムに よって実現する，GRM は経路情報を基にした監視を，LRM は観測結果から局所的に復元した通路境界の位置情報を基にし た監視を行う。通路に浻って移動する機能は, Finding Road Boundary (FRB), Moving Along Road Boundary (MARB) と Obstacle Avoidance (OA) の三つのサブシステムによって 実現する. 以下に, このシステムの動作を大まかに述べる.

ロボットの行動としては，FRB，MARB，OAの三つがあ り，それらの実行の遷移は Fig. 2 内の太線によって表現される， 最初に, FRBがロボット周辺から通路境界を検出し, それら の中から適切な通路に属する一つの通路境界を選び MARBに 送る。MARBは，その通路境界を追跡しながら，ロボットを それに沿って移動させる，MARBが，通路境界の端点を発見 したり通路境界を見失うと，FRBが新たな通路境界を探索す

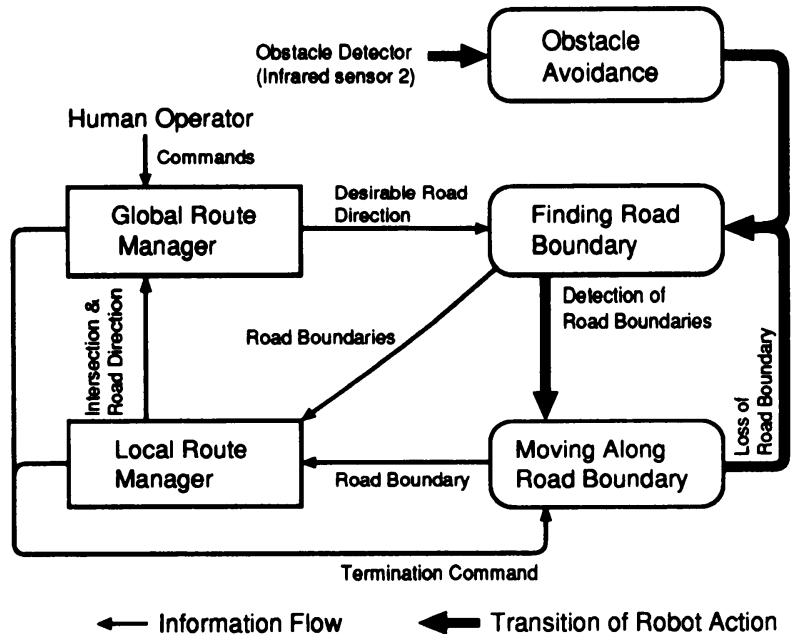

Fig. 2 System overview
るために随時動作を開始する．OA は，ロボット前方を常時監 視している光電センサ 2 によって起動される．障害物が発見さ れると, OA は他の二つの行動に優先して障害物回避行動を行 う. $\mathrm{OA}$ が動作を終えると, 通路に沿った移動を再開するため に FRBが動作を開始する。

各サブシステム間の情報の流れは, Fig. 2 内の細線によって 表現される。LRM は，FRB，MARBが検出した通路境界を 随時受け取り, 現在のロボットの位置から一定距離, 過去にさ かのほって, ロボットの軌跡に対する通路境界の位置を復元す る. そして, それらの通路境界の位置を監視することで, 交差 点を検出する．GRM は， LRM が検出した交差点が経路情報 に該当する交差点であるかを，オペレータから与えられる経 路情報を基に確認する。そして，その交差点の認識結果を基 に，ロボットの移動すべき通路の方向を生成していく．FRBが MARBに送る通路境界をこの方向を基に選択することで，口 ボットは経路に従って移動する。以下では各サブシステムの詳 細を説明する。

\section{1 グローバル・ルート・マネージャ（GRM）}

システムがロボットを目的地まで誘導するには, オペレータ によって与えられる経路情報上での自己位置を知る必要がある. GRM はオペレー夕から経路情報を受け取り，LRM が交差点 を検出する度に，その交差点が経路情報に該当する交差点であ るかを確認する，この交差点の認識結果から，経路情報上での ロボットの位置を推定して，ロボットが移動すべき通路の方向 を決定していく.

GRM は, 以下の二つ条件を満たす交差点を, 経路情報に該 当する交差点とする.

（1）その交差点が, 経路情報に記された交差点間の距離にある.

（2）その交差点からロボットの曲がる方向へ伸びる，通路境界 が存在する.

条件（1）の判断は, 経路情報に記された交差点間の距離 $(L)$ と, 内界センサから測定される前交差点からのロボットの移動 距離 $(l)$ を比較することで行う. $L$ には, 交差点の中心間を 人間がメジャーや計測輪を使って測定した值を用い，その值は $\pm 1[\mathrm{~m}]$ の誤差範囲で測定できるものとする. 内界センサから 推定される位置情報は，その原理から移動距離に従って誤差が 増加するが，ロボットの進行方向に対する移動距離の測定精度 は高いことが知られている $[9]$. 本研究のロボットが, 真つ直ぐ な通路境界に沿って MARBにより約 $40[\mathrm{~m}]$ 走行したときの誤 差を Table 1 に示す. その誤差は移動距離に対して $0.3 \%$ 未満 であることが分かる．実際の経路移動におけるロボットは，停 止, 発進を繰り返したり, 旋回のような誤差の発生を招きやす い運動をするので，その誤差の最大值 $(K)$ を $\pm 1 \%$ に見積も る.さらに, $l$ を評価する際には, その始点と終点の不確かさ を考慮する必要がある。これは，人間が考える交差点の中心と， ロボットが実際に交差点で方向を変える地点が異なるためであ る．通路の幅を $W$ とすると，その不確定さの最大值は，始点， 終点合わせて $\pm W$ となる.

以上から, $L$ は $L \pm 1[\mathrm{~m}], l$ は $l \pm(l K+W)$ の誤差範囲 を持つものとして評価する.したがって, 交差点を検出したと き，これら $L$ と $l$ が表す二つの範囲に重複する部分がなけれ 
Table 1 Measurement error of $40[\mathrm{~m}]$ running along road boundary

\begin{tabular}{|l|c|c|c|c|c|c|c|c|c|c|}
\hline & 1st & 2nd & 3rd & 4th & 5th & 6 th & 7th & 8th & 9th & 10 th \\
\hline Measured distance [m] & 40.23 & 40.19 & 40.25 & 40.25 & 40.24 & 40.30 & 40.28 & 40.18 & 40.23 & 40.28 \\
\hline Real distance [m] & 40.29 & 40.31 & 40.36 & 40.33 & 40.35 & 40.40 & 40.39 & 40.26 & 40.33 & 40.37 \\
\hline Error rate [\%] & 0.15 & 0.29 & 0.27 & 0.20 & 0.27 & 0.25 & 0.27 & 0.20 & 0.25 & 0.22 \\
\hline
\end{tabular}

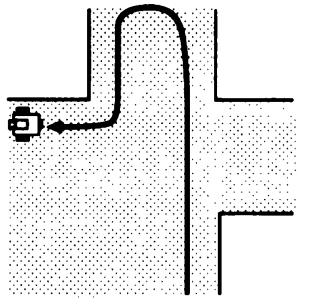

(a)

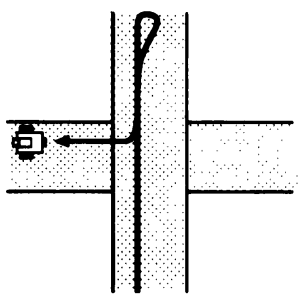

(b)
Fig. 3 Two examples of intersection

ば，その交差点を経路情報に該当しない交差点として無視する． 実験では，Wにキャンパス内の通路幅の最大值 $(4[\mathrm{~m}])$ を設 定した

条件（2）の判断は, GRM が, LRMによって復元された通 路境界群を調べることで行う. GRM は, 経路情報の交差点での 移動方向の記述を, right $=-90^{\circ}$, forward $=0^{\circ}$, left $=90^{\circ}$ と解釈する. 次に, LRM が算出するロボットが移動してきた 通路の方向に, 次交差点での移動方向の記述の值を加え, その 交差点での移動すべき通路の方向とする，そして，その方向か ら $\pm 30^{\circ}$ の範囲の方向に伸びる通路境界を確認できたならば, 経路情報に該当する交差点として認識する．なお，通路の向き に対して設定した範囲は, 交差点から伸びる各通路の方向間に $30^{\circ}$ 以上の差異があるものとして定めた

GRM は, ロボットの移動すべき通路の方向を常に保持して いる，その方向は，次のようにして生成する。ロボットが交差 点間を走行しているときには, LRM から受け取るロボットの 走行している通路の方向を移動すべき通路の方向とする. 交差 点を認識したときには, ロボットが移動してきた通路方向に, 経路情報から指示されるその交差点での移動方向を加えた方向 を，移動すべき方向とする．

環境には変則的な形状の交差点が存在し得るため, 上記した GRM の動作によるロボットの走行だけでは, LRM が交差点 を検出できない場合がある．そのような場合として, 以下の二 つが考えられる。

（1）交差点の通路幅が広い場合. (Fig.3 (a) 参照).

（2）交差点内にも連続して通路境界が存在する場合（Fig. 3 (b) 参照).

以下では, Fig. 3 の交差点 (a), (b) における GRM の動作につ いて述べる．図中のいずれの交差点においても，ロボットは下 方から交差点に進入し, 交差点で左折する指示を受けていると する。

通路幅が広い交差点では, 交差点内のロボットと通路境界の 位置関係によって, 画像上での通路境界の長さが, それを検出 するために十分な長さに満たない場合がある，例えば，交差点 (a)では交差点の角の一つが欠けているために, ロボットが曲
がるべき通路の方向とは反対側の通路境界に沿って交差点に進 入する。このとき，ロボットを誘導するために必要な，通路を 隔てて左方向に伸びる通路境界は, カメラの観測範囲（ロボッ 卜を中心とした半径 $5.5[\mathrm{~m}]$ ) に起因して, 撮像面上の一部にし か投影されない。このため，交差点を検出できず，ロボットは 交差点を通り過ぎてしまう。しかし，GRM は経路情報に記さ れた交差点間の距離と，ロボットの移動距離を比較することで， 指定された交差点を通り過ぎた事実を知ることができる．GRM は移動経路からの逸脱を認識すると，MARBに動作を打ち切 る指令を出すと同時に, 保持しているロボットの移動すべき通 路方向を $180^{\circ}$ 反転する。 その結果, FRBが動作を開始し，今 までとは正反対の向きを持つ通路境界を選択して，MARBに 送ることになる（通路境界の選択方法については 5.3 節を参照）。 したがって，ロボットは移動してきた通路を戻り，交差点を発 見することができる．

交差点 (b)の場合には, 通路境界が交差点内にも連続的に存 在する。MARB は, 通路境界の端点を見つけるか, 通路境界 を見失うまで，その追跡を実行し続ける。したがって，交差点 (b) 内では終始 MARBが実行され，FRBが起動されることは ない。その結果, LRM はMARBが追跡している通路境界以 外の境界線を得ることができないので，ロボットはその交差点 を通り過ぎてしまう。この場合にも GRM が交差点 (a)の場合 と同様に対処することで，ロボットは移動してきた通路を戻り 始める．交差点 (a) の場合との相違点は，そこまで移動するた めに利用した通路境界に再び治って移動している点である．同 一な通路境界に沿って移動しても，新しい情報を得る可能性は ないので，ここでは，新しい通路境界を積極的に発見する動作 が必要となる．そこで，GRM は，LRM から追跡している通 路境界が既知であるとの知らせを受けると，MARBに動作を 打ち切る指令を定期的に出す。これにより，FRBが一定間隔ご とに起動され，LRM が交差点を発見することができる．

また， T字形の交差点において直進する際に, 通路が交わっ ていない側の通路境界に浻って移動する場合や, 交差点 (b) を 直進する場合にも，ロボットは，交差点を発見することなく， 通過してしまう。これらの場合も，先に述べた交差点 (a), (b) の場合と同様に GRM が働くことで，交差点を発見することが できる

\section{2 ローカル・ルート・マネージャ (LRM)}

LRM は，FRB，MARBが検出した通路境界を随時受け取 り，現在のロボットの位置から過去 $8[\mathrm{~m}]$ の移動の間に検出さ れた通路境界を記憶している。そして，その間のロボットの運 動を, 内界センサを用いて復元することで, ロボットの軌跡に 対する各通路境界の位置を算出する．内界センサによるロボッ トの運動の復元は局所的に行う。すなわち, 各通路境界の向き は, 記憶されている通路境界の中で最も古い通路境界を検出し 
たときのロボットの向きを基準として表現する。

LRM は，記憶した通路境界群の位置情報を基に，以下の（1） 〜（4）の働きを行う.（1）ロボットが走行している通路の方向 を GRM に送る.(2) 交差点の検出を行う。 LRM は, ロボット が走行している通路の方向に属さない通路境界を発見すると, 交差点が存在すると判断し, GRM に知らせる. (3) 記憶された 通路境界の配置を調べ, その配置が円弧状であるとき MARB に対して動作の打ち切りを指示する。これは, 交差点の角が円 弧状である場合, ロボットがそれに沿って移動を続け, 交差点 を通り過ぎてしまうのを防ぐためである.(4) MARBから新た な通路境界を受け取ったときに, その通路境界が路面上に存在 することをモーションステレオ法 [16]を用いて確認する。これ は, FRBが通路境界として, MARBに送る直線が, 路面上に 横たわる境界線ではない可能性があるためである。

\section{3 通路境界発見 (FRB)}

FRB は, ロボットが静止している状態でビデオカメラを回転 させ, ロボット周辺の通路境界を検出する. そして, 適切な方 向と位置を有する通路境界を選び, MARBに送る。もし, 適 切な通路境界が検出されなければ， GRM から受け取るロボッ トの移動すべき通路方向にロボットを移動させ，検出を繰り返 す、ただし, その際に移動する距離は, 移動を始める前のビデ オカメラの観測範囲を越えないものとする.

FRB は最初に探索範囲を決定するために GRM から，ロボッ トの移動すべき通路方向 $(\Theta)$ を得て, ビデオカメラを $\Theta$ から $\pm 90^{\circ}$ の範囲で回転させて通路境界を検出する。通路境界の探 索が終わると, 探索された通路境界をLRMに送る。LRMで は, この観測結果を基に交差点を検出する．FRBは，その観 測結果を基に生成された $\Theta$ を用いて MARBに送る境界線を 選択する。その選択の手順は以下である.

(1) 検出された通路境界の中から, $\Theta-30^{\circ} \sim \Theta+30^{\circ} の$ 範囲 の方向に伸びている通路境界を選ぶ.

（2）（1）で選ばれた通路境界に, 次交差点で曲がる方向に存 在する通路境界があるならば，それらを選択する（例えば, 次交差点で右に曲がるなら, 通路の右側に存在する境界線 を選ぶ)。

（3）（2）から最もロボットに近い通路境界（ロボットからの垂 線の長さが最も短い通路境界) を選択する。

例えば, $\Theta=70^{\circ}$, 次交差点での移動方向が left である Fig.4 の場合, 検出した通路境界 $\{1,2,3,4\}$ の中から, 処理 (1) に より通路境界 $\{1,2,3\}$ を選ぶ. 次交差点での曲がる方向は $160^{\circ}(\Theta+l e f t)$ であるから, 処理 (2) から $160^{\circ}$ の方向に存在 する $\{1,2\}$ を選ぶ. 最後に, 通路境界 $\{1,2\}$ から最もロボッ 卜に近い通路境界 $\{2\}$ が処理（3）によって選択される。

\section{4 通路境界追跡 (MARB)}

MARBはFRBから通路境界を受け取ると, ビデオカメラの 画像から, 連続的に通路境界を検出することで, ロボットをそ れに沿って移動させる，通路境界を追跡するには，ロボットの 運動によって, 通路境界がビデオカメラの撮像面から逸脱しな いようにする必要がある。このため, 常にビデオカメラの方向 を通路境界の存在する方向に制御する。また, 画像上での通路 境界探索領域は, 通路境界が現れる位置を予測して決定する.

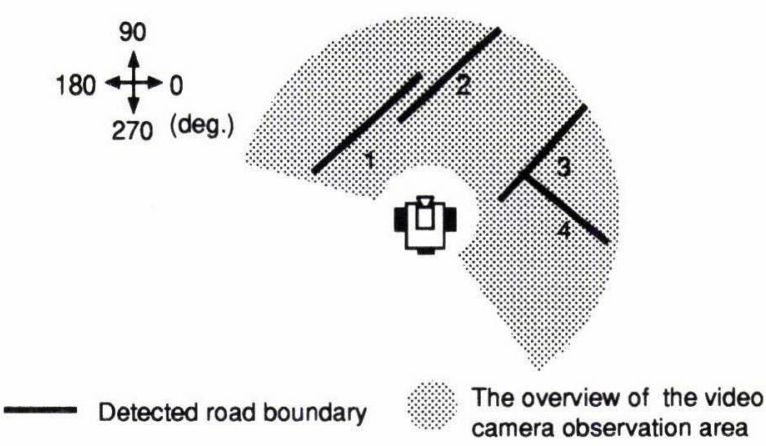

Fig. 4 Selection of a road boundary

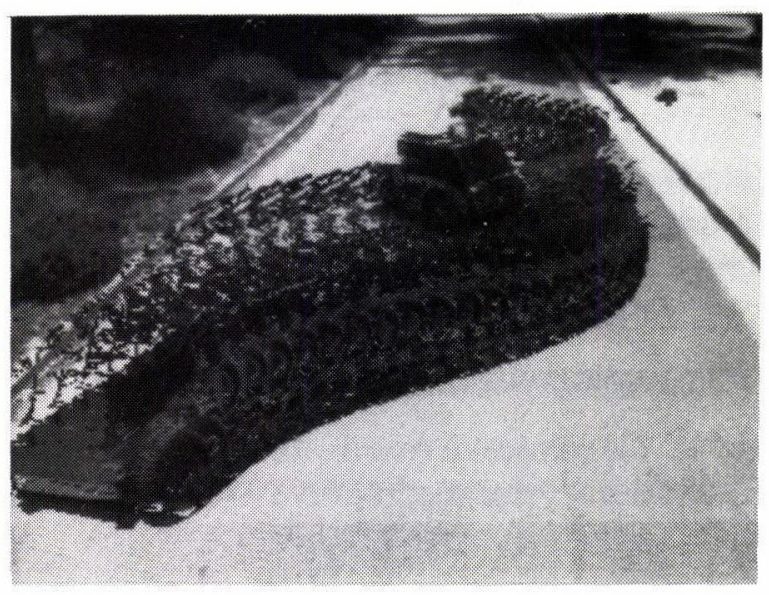

Fig. 5 Robot motion by MARB subsystem

検出された通路境界は, 随時 LRMに送る。MARB は通路境 界の端点を発見したり, 通路境界を見失うと動作を終える。

Fig. 5 は MARBが図中左側の通路境界に沿って, ロボット を移動させたときの軌跡を示す写真である。

\section{5 障害物回避 (OA)}

障害物回避に使用するセンサは, 投光部から光線を信号光と して発射し, 物体によって反射する光を受光部で検出して, 出 力信号を得る方式である. 各光電センサは, 扇型の検出領域を 持ち, センサ 1 は, 扇型の検出領域が路面に対して垂直に, セ ンサ 2 は路面に対して平行になるように設置してある.

OAの行動は, FRB, MARBの実行に優先して実行される. 車体前方に固定された光電センサ 2 がロボットの走行の障害と なる物体を発見すると，OA は動作を開始する，OA は直ちに ロボットを停止させ, 回転台に備え付けられた光電センサ 1 に より, ロボットの周辺の空間の探索を 2 度行う.そして, 時間 的に隔てた二つの探索結果の共通する障害物領域を検出するこ とで, 静止した障害物だけを検出する。これは, ロボット周辺 を歩行している人の影響を排除するためである，次に，ロボッ トの向いている方向から, 最も近い移動可能な空間の方向にロ ボットの向きを変え, その方向にロボットを移動させ, 実行を 終える、ただし, その移動距離は光電センサ 1 の観測範囲を越 えないものとする.

Fig. 6 は, OA により, 通路上の自動車を回避したときの, ロポットの軌跡を表す写真である．障害物の手前で光電センサ 


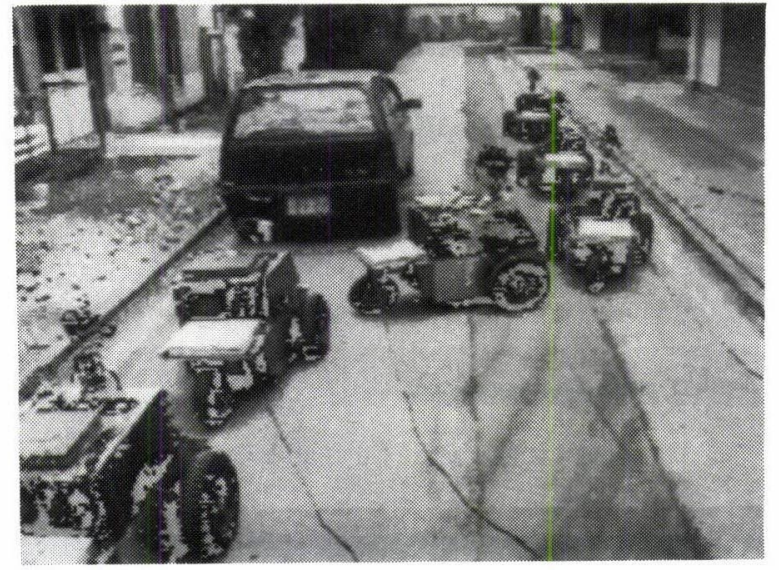

Fig. 6 Robot motion by $\mathbf{O A}$ subsystem

2 が障害物を検出し, $\mathbf{O A}$ が起動される. そして, 光電センサ 1 から移動可能な方向を知り, ロボットを右方向に誘導した後, その動作を終えている. その後, FRB, MARBが順に起動さ れ，通路境界に沿う移動を再開している。

\section{6. 通路境界発見と追跡のための画像処理}

従来の多くの道路追跡の研究では, 通路追跡の初期状態にお いて, 道路はカメラの画像に投影されるものと仮定している. 一方, 本研究の車両は, 車椅子程度の大きさであるため, 通路 上において様々な方向を向くことが可能で, 柔軟にその軌道を 変更することができる。したがって, 画像中に通路が必ずしも 含まれないために，ロボット自身が通路追跡の前に通路を探索 する必要がある。また, 同様な要因から, ロボットは車両の向 きに対して, 任意の方向に伸びる通路を, 画像処理で通路追跡 ができ, かつ, それに沿って移動できなければならない (Fig.5 参照).

通路境界は, ビデオカメラを通して得られる $320 \times 242$ (画素) $\times$ RGB (色成分), 各 8 ビットのデジタル画像から直線を検出す ることで発見する。通路境界の検出には $\mathrm{G}$ 成分のみを用いる. 直線の検出には， $\gamma-\omega$ Hough 変換 $[14]$ を用いる.この手法は, パラメータ空間における投票数に偏りがなく, 投票軌跡が区分 的な直線である特徴を持ち, 画像中の線分を正確に検出するこ とができる。

\section{1 通路境界発見の画像処理}

FRB の通路境界の検出方法を述べる. 画像上に探索領域を Fig. 7 のように画像中央に定め, Sobel エッジオペレータでエッ ジ点 (図中の白点) を検出後, それぞれのエッジ点をHoughパ ラメータ空間に投票し, その極大值を得ることで直線を検出す る.この処理は, ソフトウェア（C言語とアセンブリ言語）で 行う。ビデオカメラを回転して, この処理を繰り返すことで, ロボットの周囲から複数の直線を検出する. 一画面の処理に要 する処理時間は約 $2[\mathrm{sec}]$ である.

\section{2 通路境界追跡の画像処理}

MARBの通路境界の追跡方法について述べる.MARBは， 回転台を用いてビデオカメラの向きを制御することで, ロボッ 卜の旋回運動等にかかわらず, 通路境界を撮像面に常に保つ能

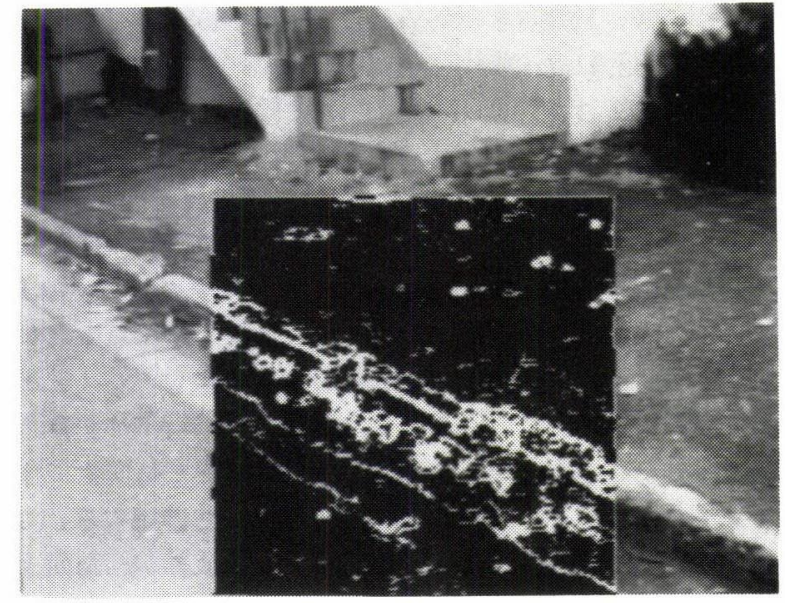

Fig. 7 Search area by FRB subsystem

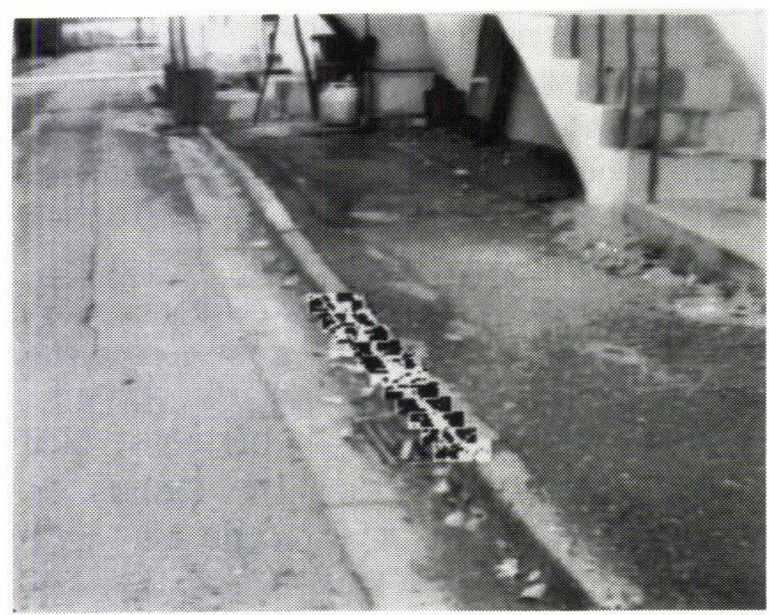

Fig. 8 Search area by MARB subsystem

力を持つ [15]. 対象とする環境の通路境界はノイズを伴うこと が多い (Fig. 7, Fig.8 参照).さらに, ビデオカメラの回転運 動とロボットの運動により, 画像上の通路境界の位置は, 画像 を取り込むごとに変化する.

そのため, 画像中での通路境界の出現位置をできるだけ正確 に予測して, その推定值を基に適切な探索領域を設定する必要 がある、MARBは前シーンで検出された通路境界の位置と, 内 界センサで測定されたビデオカメラの運動から, 撮像面に投影 される通路境界の位置を予測する $[15]$. そして, 予測された位 置に沿って, 複数の小さな矩形の探索領域を設定する (Fig.8 参照). 次に, これらの探索領域のエッジ点を同一の Hough パ ラメー夕空間に投票し, 通路境界を線分として検出する. 通路 境界の端点は, その線分の長さを調べることで発見する.

このように通路境界の出現位置を予測することで, 通路境界 を効率良く, かつ, 頑健に追跡することができる。通路境界を 検出するために要する処理時間は約 $0.2[\mathrm{sec}]$ である. 


\section{7. 実 験 結 果}

\section{1 屋外環境の特徵}

提案したシステムの有効性を検証するために，下記の特徵 を持つキャンパス内通路においてロボットを誘導する実験を

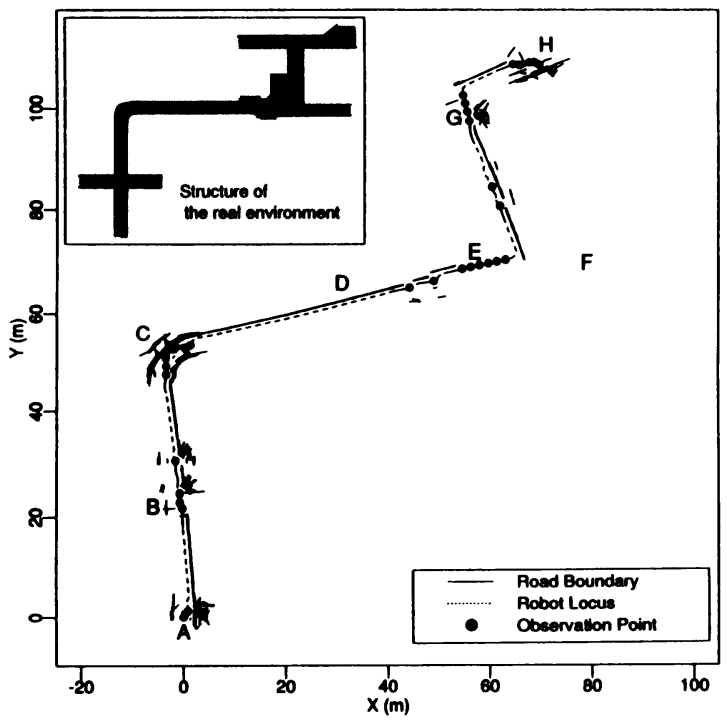

Fig.9 Experimental result in Scene 1 without any obstacles
行った.

（1）通路は，主に人の移動に利用されている.

（2）通路境界は，アスファルト道路上に描かれた白線のように 明確なものではなく，光の照射状態の影響を受けやすい．

（3）路面には, 排水のための傾斜や，部分的な修復による凹凸 が存在する (Fig. 8 参照)。このため推測航法による正確な 位置制御は難しい。

（4）通路には歩行者や障害物が存在する.

\section{2 走行実験}

Fig.9，Fig.10 および Fig.11 は，ロボットが走行している ときに LRM が局所的に復元したロボットの運動と，それを基 に算出した通路境界の位置を，目的地に到達するまで記録し， それを表示したものである.図中の波線と実線は，それぞれ ロボットの軌跡と検出された通路境界を示す。また，ロボット の軌跡上の黒丸は，FRB が通路境界を探索した地点を示して いる.

本システムの経路移動に関する頑健性は, Fig. 9 と Fig. 10 との比較により示される．実験環境とロボットに与えた経路情 報は同一である．図の一辺は約 $120[\mathrm{~m}]$ の長さを示す．経路情 報は，(forward, 23, forward, 29, right, 69, left, 34, right, 27) である.

Fig. 9 では, ロボットは点 $A$ から出発し, 交差点 $B, C, E, G$

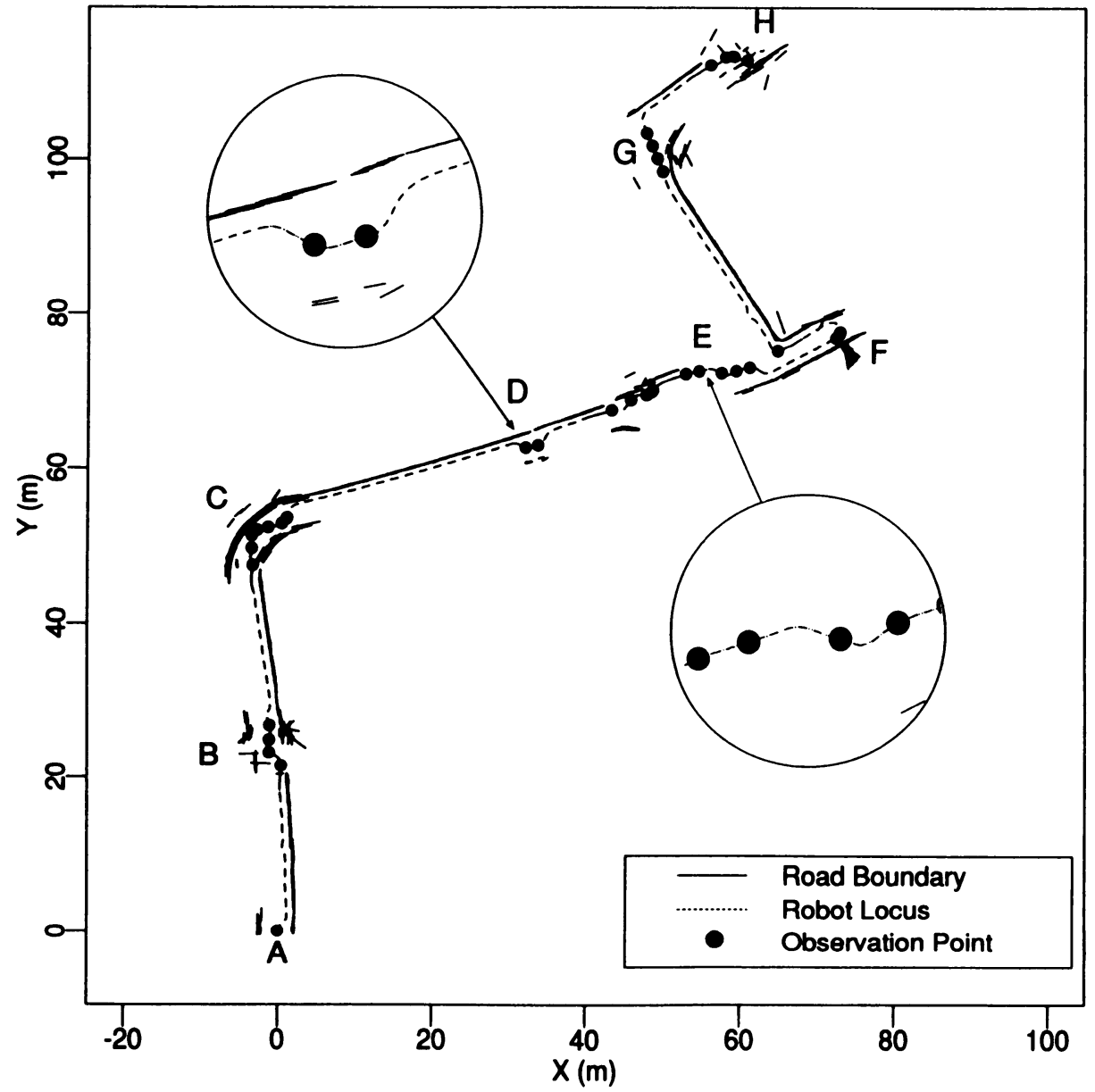

Fig. 10 Experimental result in Scene 1 with obstacles 


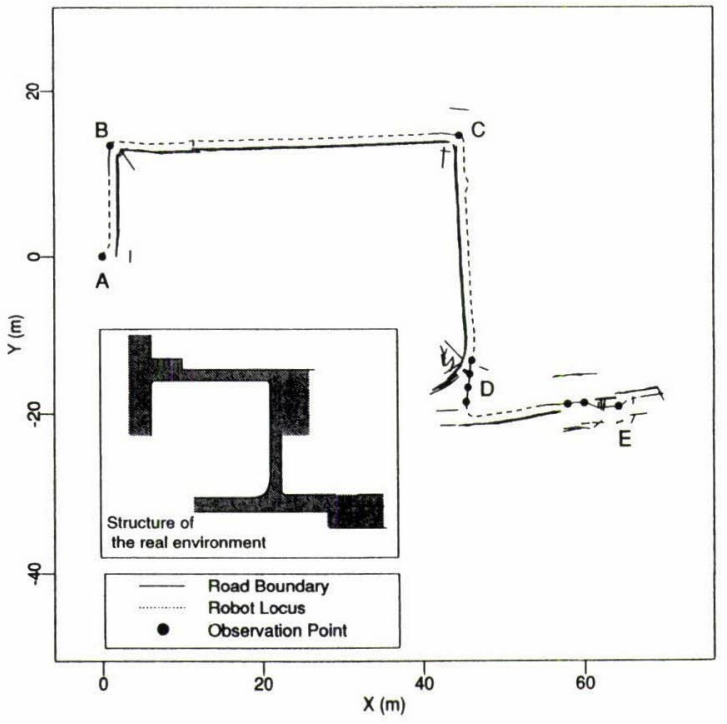

Fig.11 Experimental result in Scene 2

を通過して目的地 $H$ に到達する. Fig. 10 でも同様な道順を 移動するが，時間的な隔たりから環境状態が変化したため，口 ボットの軌跡や, 検出される通路境界は Fig. 9 といくぶん異な る部分がある. 特に Fig. 10 の点 $D, E$ 付近では, ロボットの 軌跡が大きく異なる。これらの場所では，通路のおおよそ 3 分 の1をふさぐ大きさの障害物が現れたため, ロボットはそれら の障害物を回避している。点 $E$ においては，その障害物回避 の行動が，交差点を検出する機会を失わせる原因となる。この ため，ロボットは移動経路から一度は逸脱するが，GRM がそ の逸脱を認識し，対処することで移動経路に復㷌している.

さらに本システムの妥当性を示すため, 他の場所での実験結 果を Fig. 11 に示す。経路情報は (forward, 15, right, 45, right, 34, left, 24) を与えた.ロボットは点 $A$ から移動を始め, 点 $E$ まで走行した。なお，いずれの実験でもロボットの移動速度は $20[\mathrm{~cm} / \mathrm{sec}]$ である.

屋外環境を移動するロボットは，影が存在する通路を移動す る場合がある、影は，視覚移動ロボットの画像処理結果に大き く影響を与える。例えば, Fig.12 に示す環境では，通路には 樹木の影がまばらに存在する。この状態の影は, 一様に広がる 影よりも，通路境界検出に与える悪影響は大きいと考えられ る。この領域にロボットが進入したときには，MARBの通路 境界の検出結果が乱れ，車体の軌跡が $\pm 5[\mathrm{~cm}]$ 程度の範囲で蛇 行気味になり,さらに影の影響が大きい地点では, MARBに よる通路境界追跡が不可能になった。しかしながら，見失った 地点で随時，FRBによる通路境界の探索が起動されることで, 再び通路境界を発見し，MARBが動作を再開することが可能 であったＦig.12 の場面では，MARBが一時的に通路境界を 3 回見失った。このようにして, 影が存在しても, 通路境界の 探索, 追跡を繰り返すことで, 通常より長い通過時間を要する が, 経路移動を続けることが可能であった. だが, 交差点付近 に鮮明で直線的な輪郭を持つ影が存在する場面では, システム がその輪郭を通路境界として誤認識し，通路から逸脱すること

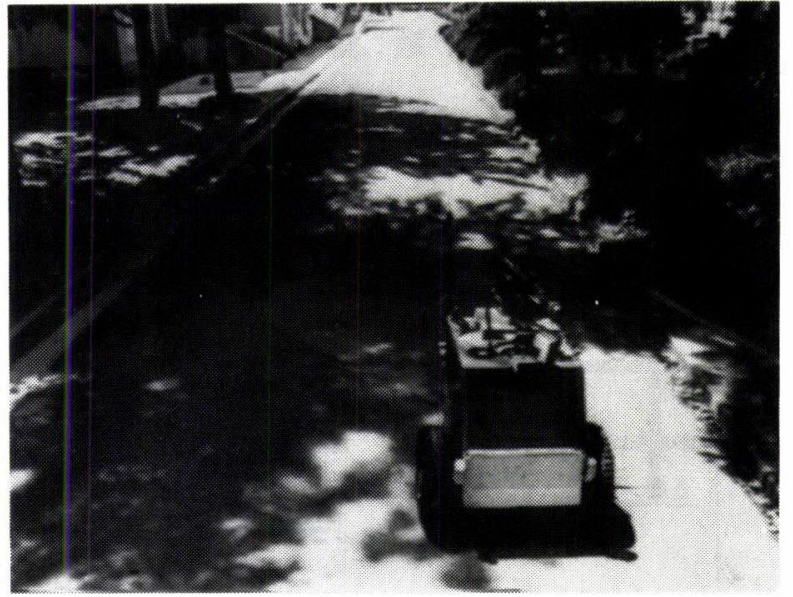

Fig. 12 Robot motion under shaded area of road environment

があった。

屋外環境に扔いて, 簡潔な経路情報を基にして頑健な誘導を 実現した要因として，以下のことが考えられる。

（1）システムが環境内の通路を自律的に発見して，それに沿つ て移動する能力を備えている

（2）システムは, ロボット周辺の局所的に復元した通路境界の, ロボットに対する相対的位置情報を参照して，ロボットを 誘導している.

（3）通路を検出する特徴として, その境界線を利用している.

（4）画像上での通路境界の追跡のとき，画像上でその投影され る位置を予測している。

（5）環境状態に応じて, 通路境界の発見, 追跡のサブシステム を繰り返し実行している.

ロボットを誘導するために必要な経路情報を, 交差点に関す る記述で簡潔に表現できるのは, システムが通路を発見し, 通 路に沿って移動する能力を備ているためである.

Fig. 9 の目的地 $H$ における通路境界の向きと, 図内左上の 通路環境の概略図の通路の向きとを比較すると, 約 $30^{\circ}$ の差異 があることが分かる、これは, ジャイロから得る方位が, 振動 などのために徐々にドリフトするためと考元られる．このよう な䛊差は，内界センサを使用する上で避けることはできない． しかし, システムは, 局所的に復元した通路境界の位置情報を 参照して動作しているので, この種の誤差の影響を受けずに， ロボットを誘導することができる。

通路の特徵として, 直線状の視覚パターンである通路境界を 用いたことが, 屋外環境での頑健な通路の発見, 追跡を実現し た。すなわち，通路境界を検出することは，ノイズに強い特性 を持つHough 変換 [17] を用いて, 画像から直線を検出するこ とに置き換えられるためである。

さらに, 通路境界の追跡に関しては, 画像上に出現する通路 境界の位置を予測して設定したことが, Hough 変換の利用と 併せて頑健な通路追跡を実現した。この予測により，画像上の 必要な領域だけを処理対象にできるので, 画像上の他の視覚パ ターンによって, 検出が乱されることが極めて少なくなる。ま た，画像処理の高速化を自ずとはかることができる. 
通路境界の端点や通路境界を見失った地点で, 随時, 通路境 界の探索を行い，発見した通路境界から，その場その場の適切 な通路境界を選択して移動することは，実環境に適応した口 ボットの行動を実現している。それゆえ，システムは一般的な 通路環境に想定される環境の変化（障害物や太陽光に起因する 通路境界の見かけの変化）に, 対応できる能力を有する。

\section{8. ま と め}

本稿では, 通路を発見, 追跡する能力を基に環境内を移動し， 簡潔な表現で記述された経路情報から目的地までロボットを誘 導するシステムを提案した。システムはロボットを自律的に通 路に沿って移動させる機能と, 指示された経路から逸脱しない ようにロボットの運動を監視する機能から構成される.

システムの有効性を示すために，障害物やノイズを含む画像 等の視覚移動ロボットの経路移動に関して外乱となる要因が存 在する屋外環境において実験を行った。その結果, システムが 長距離にわたって安定にロボットを目的地に誘導することを確 認した。

システムの適用例としては, 本稿で提案した経路表現によっ て記述された地図を用いた案内ロボットなどが考えられる。

$$
\text { 謝 辞 }
$$

本稿をまとめるにあたって, 貴重な助言をいただいた石黒浩 氏（大阪大学基礎工学部）に深く感謝いたします。また， $\gamma-\omega$ Hough 変換のソースプログラムを提供していただいた和田俊和 氏（岡山大学工学部），ロボットの製作において適切な指導を いただいた茅野之雄氏（山梨大学機械工場）に感謝いたします.

なお, この研究の一部は, 平成 $3 \sim 5$ 年度文部省科学研究費 C (03650343)，富士ゼロックス(株)，人工知能財団の奨学寄付金 の援助を受けた。

\section{参 考 文 献}

[1] 松本, 油田：“経路地図に従った移動ロボットの自律走行システム”,
日本ロボット学会誌, vol.5, no.5, pp.19-27, 1987.

[2] A. Kosaka and A.C. Kak: "Fast Vision-Guided Mobile Robot Navigation Using Model-Based Reasoning and Prediction of Uncertainties," in Proc. IEEE/RSJ Int. Conf. on Intell. Robots and Systems, pp.2177-2186, 1992.

[3] F. Chenavier and J.L. Crowley: "Position Estimation for a Mobile Robot Using Vision and Odometry," in Proc. IEEE Int. Conf. on Robotics and Automation, pp.2588-2593, 1992.

[4] 小森谷, 舘, 谷江：“移動ロポットの自律誘導の一方法”, 日本ロボッ 卜学会誌, vol.2, no.3, pp.46-55, 1984.

[5] 津村, 橋本, 藤原：“レーザとコーナキューブを利用した三次元移動 体の能動位置計測法”, 日本ロボット学会誌, vol.6, no.1, pp.222-231, 1984.

[6] C. Thorpe, et al.: "Vision and Navigation for the Carnegie-Mellon Navilab," IEEE Trans. Pattern Anal. Machine Intell., vol. 10, no.3, pp.362-373, 1988.

[ 7 ] E.D. Dickmanns and V. Graefe: "Application of Dynamic Monocular Machine Vision,” Machine Vision and Application, vol.1, pp.241-261, 1988.

[8] 尾崎, 清水, 吉田: “自律走行車 PVS 用動画適応型視覚システム,” 画像の認識・理解シンポジウム講演論文集 $2, p p .447-454,1992$.

[9] 山本, 丹下, 荒川, その他: “自律型無人車の位置方位測定システムと 走行性能”, 第 3 回日本ロボット学会学術講演会予稿集, pp.247-248, 1985.

[10] 小野口, 渡辺, 岡本, 久野: “移動視覚のための多重地図”, 日本口 ボット学会誌, vol.11, no.3, pp.99-107, 1993.

[11] 長谷部, 大西, 杉江：“自律移動ロボットのための定性的な環境地図 の獲得と利用”, 日本ロボット学会誌, vol.9, no.3, pp.335-339, 1991.

[12] 森, 小谷, 石黒, 安富, 茅野: “構内通路を走行する自律移動ロボッ ト”, 日本ロボット学会誌, vol.5, no.5, pp.29-42, 1987.

[13] 安富, 茅野, 二木, 森: “屋外移動ロボット晴信 4 号機の走行制御と 定形行動”, 第 5 回日本ロボット学会学術講演会予稿集, pp.339-342, 1987.

[14] 和田, 藤井, 松山：“ $\gamma-\omega$ 八フ変換一可変標本化による $\rho-\theta$ パラメー 夕空間のひずみの除去と投票軌跡の直線化一, ”電子情報通信学会論 文誌, vol.J-75-D-2, no.1, pp.21-30, 1992.

[15] K. Nishikawa and H. Mori: "Rotation Control and Motion Estimation of Camera for Road Following," in Proc. IEEE/RSJ Int. Conf. on Intell. Robots and Systems, pp.1313-1318, 1993.

[16] 伊藤, 宮内, 小沢：“移動ロボットのための単眼視による距離情報の 抽出”，電子情報通信学会論文誌, vol.J-67-D, no.3, pp.265-272, 1984.

[17] 松山, 長尾：“Hough 変換の幾何的特性と直線群検出への応用”, 情 報処理学会論文誌, vol.26, no.6, pp.1069-1078, 1985.

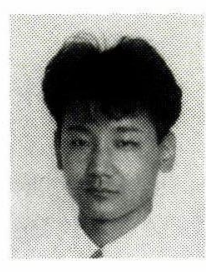

西川和弘 (Kazuhiro Nishikawa)

1967 年 4 月 7 日生. 1992 年山梨大学大学院修士課 程計算機科学専攻修了. 現在同大学大学院博士課程 社会情報システム工学専攻在学中、ロボットビジョ ン, 自律移動ロボットのナビゲーションなどの研究 に従事. 情報処理学会, 電子情報通信学会, IEEE の学生会員.

(日本ロボット学会学生会員)

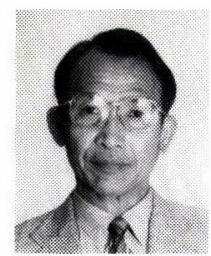

\section{森 英雄 (Hideo Mori)}

1938 年 3 月 5 日生. 1961 年東京工業大学電気工学 課程卒業. 同年富士通 (株) 入社. 1965 年山梨大学 工学部電子工学科講師, 現電子情報工学科教授. 眼 を持つ自律移動ロボットの研究と,その応用として 歩行ガイドロボット, 白線引きロボットの研究開発 に從事. 工学博士. 情報処理学会, 計測制御学会, 日本心理学会などの会員。 